\title{
9 \\ Ethnicity, Politics and Constitutions in Fiji
}

\author{
Yash Pal Ghai
}

It is clear that Fiji's constitutions hitherto have not enabled us to adequately deal with our problems. It is therefore necessary to adopt new approaches to constitution making, and imaginative and creative thinking on the design of our national institutions ... We must think of new ways to regulate relations among our citizens and the state.

Brij V. Lal (1998: 117).

For an historian, Brij Lal has displayed a keen interest in contemporary constitutions and constitution-making, reflecting his concern with and involvement in politics. Constitutions and politics are inseparable in the

1 I have drawn on a number of my publications in the writing of this chapter, particularly Ghai 1988a, 1988b, 1988c, 1988d and 1989; Ghai and Cottrell 2007: 159-92; Ghai and Cottrell 2008; Cottrell and Ghai 2010.

I have also participated in discussions and negotiations on constitution-making in Fiji. In 1988, I was an adviser to the coalition government led by Dr Timoci Bavadra after its overthrow (having rejected a similar position in the caretaker government headed by Ratu Mara), especially on the Deuba Accord, and I was an adviser on its submission to the Constitution Inquiry and Advisory Committee; in 1996 I was principal adviser to the National Federation Party and the Fiji Labour Party in their submission to the Reeves Commission; in 2008 I was adviser to the UN Secretary General on the UN's engagement in the reconciliation process in Fiji; and in 2012 I chaired the Fiji Constitution Commission. Its draft constitution was banned and rejected by the prime minister and the attorney-general, without giving the public a chance to comment on it and a constituent assembly to debate it.

In most of my work and writings about Fiji, I have received much assistance from Jill Cottrell. I am grateful to her and Coel Kirkby for helpful and insightful comments on an earlier draft of this chapter. 
South Pacific, particularly in Fiji. The constitution has seldom been far from Fiji's social, economic and political life. Constitutions in colonial and postcolonial states play roles different, in some respects, from those in more 'mature states' - certainly more ambitious, often simultaneously promoting and nurturing nationhood and the state. It is hard to understand the significance of constitutions in Fiji without immersing oneself in Lal's writings. I take the twin themes of this chapter from those in the quotation above: new approaches to constitution-making and new ways to regulate relations among citizens and the state. I also say something about relations between citizens and communities as well as the values and principles embedded in the constitution.

The several Fiji constitutions have been formulated through a variety of methods, in different contexts, with changing casts of individuals, community and the key decision-making bodies. There have been differences in contexts: pre-independence to post-coups, changing economy and notions of democracy, internal and external migration and variations in demography, literacy, education and skills, and so on. Decision makers on the constitution, and the degree of participation, has varied from a small, privileged group to the engagement of villagers in the remotest parts of the country. Processes have varied from the highly parochial to the global — with external influence and involvement and the incorporation of international norms. The method of adoption of the constitution has ranged from the relatively democratic to the most authoritarian, decreed and managed by the executive head of the government.

On relations between state and citizens, the experience of Fiji provides a number of valuable insights into the dynamics of politics and appropriate ways of structuring the state in multiethnic societies. Its multiethnic origins lie in colonialism, which not only has been globally the greatest creator of multiethnic political entities, but has also fashioned policies and institutions for the communities of such entities, yet is paid too little attention in contemporary studies of multiethnic states. The constitutional framework for the rights of citizenship and the organisation of state and power in Fiji since independence has been more critical than economic or social factors because of ethnic fragmentation and the dominance of the public sphere. There have been sharp divisions of opinion throughout its modern history between those advocating an integrated, non-racial state, based on individual rights (including equality), and those in favour of a political order based on ethnic communities. For a long time, citizenship in Fiji was subordinated to ethnicity. 
Integration and consociation are perhaps not apt terms to categorise the division, but certainly there are echoes of this antithesis. ${ }^{2}$ Many features associated with consociation have been present in the colonial and the postcolonial constitutions (such as separate communal representation, group rights, asymmetrical autonomy, power-sharing, separate educational systems, and entrenchment of rights to culture and land). Indigenous peoples' rights have been invoked, adding an extra twist to the integration-consociation polarity. But there have also been strong pulls towards political integration and broad-based, non-ethnic social justice policies. Fiji's experience shows that this polarity has limited intellectual or policy value. Consociation easily (and in Fiji's case seamlessly) slides into hegemony.

\section{Independence constitution}

\section{Making of the constitution}

Since independence, Fiji has had four constitutions, the first in 1970 and the latest in 2013. Constitutions terminating colonial rule are a sort of rite de passage to formal statehood for the territory and membership of the international community, becoming the focus of considerable attention and energy, determining the future form of state and politics. The colonial power becomes both the mediator between competing local communities and a partisan party-the latter especially if the colonial power has interests it wants to protect.

In Africa the impetus for independence came from local leaders, but in the South Pacific local leaders were generally not keen on independence, unsure perhaps of their ability to govern a new state and cope with the diversity of ethnic groups. Fiji was unusual in that the immigrant community of Indo-Fijians, by then outnumbering the indigenous Fijians, partly inspired by the struggle in India, supported independence, while the indigenous community opposed it, comfortable with British rule in which they enjoyed a superior status, with protection of their land rights and traditional institutions. But British appetite for further colonial

2 There is now considerable literature on consociation, by its supporters and opponents. A recent edited book that surveys the pros and cons of consociation is Choudhry (2008). The classical literature on the subject suggests that consociation is a modern western invention, but in reality consociation existed in empires in Asia and the Ottoman Empire for centuries. 
rule had subsided, and the leaders of the indigenous community came under some pressure to accept independence. With the encouragement of Britain, discussions on independence began in the late 1960s between political parties, dominated by those of Indians and indigenous people. Perhaps because of the competing interests of the two communities, the discussions were held in great secrecy, in the expectation that agreement would be easier this way (a distinguished US political scientist favours closed negotiations for this reason). ${ }^{3}$ This meant that people played little role in their future constitution.

Serious differences between the parties focused on the desirability of independence and the electoral system. A meeting of all the Legislative Council members was held in London, where some differences were resolved, through mediation, or more accurately, imposition by the British. The people of Fiji knew little about the issues discussed. The secret negotiations resumed on return to Fiji; only four active members from each party were involved; the papers and minutes were kept confidential. ${ }^{4}$ There was little evidence of consultation by participants even with members of their own parties, despite complaints by their members and the Council of Chiefs. Lord Shepherd of the British government persuaded the negotiators to report on progress to the Legislative Council, shortly before the final constitutional conference in London in April 1970.

There was considerable confusion as to what the parties had agreed upon in the committee in Suva. British intervention was necessary to resolve several outstanding issues, and on elections agreement was possible only on the condition (put forward by Indo-Fijians) that the system would be reviewed after the first general elections. Reaching a settlement on the independence constitution in Fiji was harder than in any other South Pacific state, with the possible exception of New Hebrides/Vanuatu, but the debates in New Hebrides were fierce-and public. Looking at the 1970 constitution, one may get the impression-perhaps unfairly — that the leaders were more concerned with their own deals than the good of the country.

3 Jon Elster argues the virtues of constitution-making in secrecy because decision makers feel less threatened by pressure groups, can have free and frank discussions, and feel it is easier to change their minds when faced with a fairer alternative. The negative side is that there is lesser legitimacy of decisions, in part because of suspicions of motives of decision makers. See Conference on Democratic Transition and Constitution, 19-27 October 2001.

4 In 1986 when I began my study of the Fiji independence process, the records of the committee were still not publicly available. The late Ahmed Ali kindly loaned me the records—secretly—and I was not to make a photocopy! 


\section{Orientation of the constitution}

The origins of the social, political and economic organisation of Fiji (largely adopted in the independence constitution) lie in British policies in the late nineteenth century (see France 1969). They were based on preservation of indigenous Fijian institutions (as understood, or even sometimes created, by the British), ${ }^{5}$ particularly the chieftaincy, land and customary practices, which served both moral (protection of the vulnerable) and administrative convenience (indirect rule). Economic development was based on foreign, principally Australian, capital, largely invested in the sugar industry, and indentured labour recruited from India. The various communities of colonial Fiji-Fijians, 'Europeans', Indians, Chinese, 'part-Europeans', and 'others', who included Chinese and other Pacific Islanders, including Rotumans and sometimes partEuropeans - were segregated by race, which determined their entitlements, political rights and economic situation; there was no sense of a common political community or identity. Thus colonial policies both created and sustained these communities as distinct bodies.

The segregation of these communities and the isolation of indigenous people from the market meant that the relations among them were largely determined by administrative policies. This points to the importance of the political. Colonial history is interpreted largely in terms of administrative regulation, even the creation of racial claims and relations. ${ }^{6}$ The effect of these policies, treating each community as a corporate entity, was to obscure the differences internal to each community.

The 1970 constitution hovered uneasily between integration and consociation. Other communities would generally provide political support to indigenous Fijians, as there were greater links between them and indigenous Fijians than with Indo-Fijians. It was on this assumption that the systems of elections and government were incorporated into the independence constitution. ${ }^{7}$

5 The Great Council of Chiefs, for example, as a formal institution was a colonial creation, as was, to a considerable extent, the 'customary' land tenure system. See Abrahamson 2009: 269 and esp. 271-72. As in Africa, perhaps even the 'traditional' identities that people adopt are the creation of the colonial powers.

6 See Lal 1992, an outstanding study of Fiji's history.

7 Indo-Fijians (close to 290,000) outnumbered Fijians (250,000) at independence, with minorities holding the balance (in favour of Fijians). After the 1990 coup, Fijians outnumbered the Indo-Fijians substantially, due to a higher birth rate, and the emigration of Indo-Fijians — so that Fijians did not have to rely on minority support (reflected in the separation of South Pacific voters from the roll of Fijians). 
The constitution provided separate representation for the principal communities but, to meet the Indian insistence on a non-racial electoral system, some seats were racially allocated but voted for by electors of all races. Twenty-seven House of Representatives seats were ethnically elected (12 each for Fijians and Indians and three for 'Others'), 25 were voted on a common roll (10 each Fijians and Indians, and five 'Others') (1970 Constitution, Section 32). In the Senate, established principally to safeguard Fijian interests, eight members were nominees of the Great Council of Chiefs (GCC), seven were appointed by the prime minister, six by the leader of the opposition, and one by the Council of Rotuma (a small, remote island inhabited by Polynesians).

Various provisions protected the interests of indigenous Fijians, including their communal ownership of land (about 83 per cent of all land in the country, though not always the best land), preservation of their traditional social and political structures that were woven into the apparatus of the state. The Senate could veto certain legislation affecting indigenous Fijian privileges. A standard bill of rights protected all citizens, ${ }^{8}$ but was qualified by the various collective rights for indigenous Fijians. The 1970 settlement was a mix of the democratic and the oligarchic, liberalism and ethnic separatism, equality and paramountcy of indigenous Fijians, market with restrictions on land and labour, a unitary state with significant autonomy for one community only, and freedom of religion with the close relationship of one religion (Christianity practised by indigenous Fijians) to the state. The system depended on maintaining the separation of races, or more accurately, keeping Indo-Fijians outside the alliance of others.

Notwithstanding the cross-voting national seats, the logic of the political system was dictated by the communal seats. Political parties were essentially racially organised to compete for the communal seats. The need to contest national seats was designed to compel each of the major parties to extend its appeal beyond the community they principally represented. For the most part this was not successful, each party being content to field a few candidates of other races. Native Fijian candidates sponsored

8 Based on the European Convention of Human Rights, found in most 1960s-1970s constitutions of former British colonies. In the Pacific, the Solomon Islands constitution is a prime example. 
by the dominantly Indo-Fijian National Federation Party (NFP) were successful through Indo-Fijian votes, and so on. ${ }^{9}$ In this way, cross-voting seats became an extension of communal seats.

This 'consociational' element in the voting was not reflected in the executive, designed on the Westminster parliamentary system of majoritarianism and the 'winner takes all'. The allocation of seats in the House of Representatives was such that, with a little support from their traditional allies, indigenous Fijians would dominate the executive. And any notion of what may be called 'sequential power sharing'as in 'normal' situations, the major parties alternate in government-was, deliberately, excluded in the Fiji context.

Every government after independence was run by the Alliance Party, with Ratu Kamesese Mara as the prime minister, even in 1977 when his party lost to the dominant Indian party - a temporary hitch because, through a combination of Indian dithering and the natural inclination of the governor-general, Mara was asked to form government. A more serious challenge appeared in 1987 when an alliance of the NFP and the multiracial Fiji Labour Party (FLP) won, and its leader Timocy Bavadra became prime minister. Within the Fijian community, the new alignment reflected the distinction between the traditionalists and those who saw the communal lifestyle and politics as holding back the development of the Fijian community (the division to some extent reflected the differences between Fijians of the east and the west of the country). The constitution came under stress, as the fundamental assumptions of the protective policies about indigenous Fijians seemed to come apart, not only in terms of new emerging identities, but also because of the imperatives of the economy: incentives and efficiency could not be maintained in the face of the interaction of 'customary' rules and the market economy. Bavadra's government did not survive long: it was overthrown by an army officer, Sitiveni Rabuka, in May 1990. Though the coup was defended as the preserver of traditional chieftaincy, it marked the end of chiefly power and a swing to the commoners. But this was not evident from the constitution

9 A note on terminology: traditionally the indigenous inhabitants have been known as Fijians, and the second-largest community as Indians or more recently Indo-Fijians. The 1997 constitution called the country 'Fiji Islands' so the people 'Fiji Islanders'. The terminology did not 'take' well. The Bainimarama government wanted everyone to be 'Fijians' and the indigenous 'iTaukei' (people of the land in Fijian language). Here for the sake of simplicity I retain 'Fijian' to mean the indigenous communities. 
with which Rabuka brought the independence settlement to an end. Under him, the constitution-making process became the means to wage racial strife by another name. ${ }^{10}$

\section{The 1990 constitution}

\section{Making of the constitution}

As soon as a degree of public order was restored to Suva, and the government headed by Rabuka was installed, the governor-general set up a Constitution Review Committee in which the ousted coalition under Bavadra reluctantly agreed to take part though heavily outnumbered by Alliance and Great Council of Chiefs members. It was chaired by Sir John Falvey, a former attorney-general close to indigenous Fijians. ${ }^{11}$ It was to review the constitution of Fiji and propose to the governor-general amendments to guarantee indigenous Fijian political interests 'with full regard to the interests of other groups'. The composition as well as terms of reference of the Committee favoured indigenous Fijians. Nevertheless, the process was more participatory than that for the 1970 constitution, though more manipulated (which often comes with participation). For the first time in Fiji, people had opportunity to give their views. The Committee held hearings in the four major towns and received over 860 written submissions and 120 oral submissions. ${ }^{12}$ But the atmosphere in which these consultations took place was hardly conducive to any conciliatory recommendations. The Indo-Fijian community wanted a return to the 1970 constitution, while most Fijian individuals and groups wanted to enshrine Fijian dominance, differing only in the smallness of the role they would give to the Indo-Fijians.

The Committee recommended a unicameral legislature comprising 36 Fijians (28 elected and eight appointed by the Great Council of Chiefs), 22 Indo-Fijians, eight General Electors, one Rotuman, and up to four nominees of the prime minister. National constituencies, ethnically

10 Rabuka actually carried out two coups. The second (in September) forestalled the coalition caretaker government agreed upon in the wake of the first coup.

11 The Committee had available the services of a retired professor of law from the UK, Keith Patchett.

12 Lal (1992: 286-89) gives an account of the Commission, including of some of the submissions to it. 
allocated by those elected by universal suffrage, were to be abolished, and all voting was to be communal. The prime minister's post was to be reserved for an indigenous Fijian.

Six members of the Committee, including all the Indian members dissented. As the process was leading nowhere and the economy was suffering from public disorder, the governor-general abolished Parliament and assumed executive powers-appointing Rabuka as the Commander of the armed forces. The governor-general convened a meeting on 24 September 1987 between political parties. On 27 September, the parties reached an agreement (the Deuba Accord) under which an interim government with members drawn equally from the two main parties would be established, and which would set up a new Constitution Review Committee (under a foreign expert) to propose a constitution acceptable to all, taking into account the aspirations of all communities.

Rabuka's response was rapid - on 28 September he carried out the second 1987 coup, declared Fiji a republic, and set up a government headed by himself and dominated by indigenous Fijians. He was soon replaced by Ratu Mara, thus returning the country to civilian, if not constitutional, rule.

Unlike the independence constitution, which was an elite-negotiated document, the 1990 constitution was more or less imposed on the people, in the face of unanimous opposition of one major community, Indo-Fijians, and considerable opposition from other communities. Having prepared its own draft (see Lal 1998: 10-11), heavily in favour of indigenous people, the Rabuka government set up the Constitution Inquiry and Advisory Committee chaired by a retired colonel, Paul Manueli, and weighted against Indo-Fijians. Its terms of reference were related strictly to the public reaction to the government draft, and to making proposals based on that reaction (Manueli 1989). Ratu Mara described the process: 'Citizens throughout the country were given the opportunity of making their views known, and eminent legal experts were called on for advice' (Mara 1997: 223). I had a different view: the committee was handpicked by the government and enjoyed neither popular support nor public credibility; the people had no effective participation and the constitution was to be brought in by force by the government (Ghai 1991). Brij Lal's evaluation of the process was less harsh, pointing to public meetings organised by the committee and oral and written submissions received (Lal 1998: 12). 
Among the submissions received by the Committee was one from the military, which advocated 'absolute political dominance' by indigenous Fijians, ${ }^{13}$ with controls on the press, judges appointed who would 'accept the situation', and the workers and the church cut off from what were viewed as subversive foreign influences, while the nation was subject to military discipline, and deprived of constitutional rule, for 15 years. ${ }^{14}$

\section{Orientation of the constitution}

The Manueli report, and the constitution based on it, were both racially based. Elections were to be entirely on an ethnic basis, with 37 seats for indigenous Fijians and 27 for Indo-Fijians out of 70 seats in the lower house. An appointed upper house was over two-thirds Fijian. Only an indigenous Fijian could be prime minister, and the president was appointed by the Great Council of Chiefs (GCC). There was a similar imbalance in the Senate. The over-representation of Fijians when they also had an absolute majority in the other house turned the justification of the second chamber on its head. Greater powers were granted to the executive than before, since the moderating role of the leader of the opposition (traditionally an Indo-Fijian) was removed and the prime minister had a direct and decisive say in appointments to various offices. The legislature and the executive were given unlimited powers to establish programmes and policies for 'promoting and safeguarding the economic, social, educational, cultural, traditional and other interests of the Fijian and Rotuman people' (s. 21(1) Constitution). Minerals were vested in the owners of the land underneath which they were found-a major shift of resources from the state to one community. The constitution enhanced the role of indigenous institutions, including the Native Land Commission, the Native Fisheries Commission, and the Native Lands Trust Board, removing review by the courts and the ombudsman of their decisions and acts.

What dominated Fijian elite views at this period were not just the question of the Indo-Fijian bogey, but also an outdated perception of Fijian society-rural, land-linked, chief-dominated and cohesive. The constitution of 1990 was biased towards rural Fijians (the 33 per cent of Fijians who lived in urban areas having only 13.5 per cent of the parliamentary seats). Many of the native institutions could not,

13 For the links between the military, religion and Fijian chiefly tradition, see Halapua 2003.

14 See Lal 1998: 14 for other measures proposed by it in favour of indigenous people. 
as previously stated, be regarded as indigenous, but as instruments of those Fijians who controlled the state. Close control by native institutions by the state precluded other races from influence on state policies and undermined the capacity or willingness of the state to promote interethnic bargaining and accommodations. At the same time, these institutions were used to discipline Fijians as a racialised, dominant group separate from other citizens-thus amplifying their social, legal and economic segregation. ${ }^{15}$ It gave a far more prominent role than in the past to the GCC, and thus greater control of the eastern chiefs over the western.

The coalition parties participated in elections held under this constitution in 1992, after a good deal of soul-searching (the differences over whether to participate actually broke the coalition). The election led to Rabuka becoming prime minister as an elected politician rather than as a coupmaker. (We cannot know how the history of Fiji might have been different if Bavadra, a statesman committed to the vision of a non-racial and just Fiji, had not died before the elections). Ironically, however, the constitution reinforced internal divisions among Fijians. Once Indians were sidelined, there was little to maintain the political unity of Fijians. The passing of power to commoners undermined the chiefly class, which had sedulously cultivated the ideology of traditionalism, and a sort of unity under eastern hegemony. No Fijian party, given the multiplicity of parties among Fijians, could form a government without the support of an Indian party. Needing Indian support to form a government, Rabuka agreed to a speedy review of the constitution.

\section{The 1997 constitution}

\section{Making of the constitution}

The failures of the 1970 and 1990 constitutions prompted the search for a new basis for the state and intercommunity relations, based on national harmony and equality. After considerable negotiations between the Rabuka government and the Indo-Fijian political parties, agreement was reached that an independent commission would undertake the review of the 1990 constitution and make recommendations for change. The Chair was the distinguished New Zealander Sir Paul Reeves (former governor-

15 I am grateful to Coel Kirkby for this insight. 
general of his country), veteran politician Tomasi Rayalu Vakatora and The Australian National University Indo-Fijian scholar Brij Lal. The objectives of the review were the promotion of 'racial harmony and national unity and economic and social advancement of all communities, and bearing in mind internationally recognised principles and standards of individual and groups rights' (though there was a sort of proviso: the constitution 'shall guarantee full protection and promotion of the rights, interests and concerns of the indigenous Fijian and Rotuman people' (Reeves, Vakatora and Lal 1996: 2) The commission was to:

facilitate the widest possible debate throughout Fiji on the terms of the Constitution of Fiji and to enquire into and ascertain the variety of views and opinions that may exist in order to formulate provisions of a Constitution that would meet the needs of a multi-ethnic and multicultural society (Reeves, Vakatora and Lal 1996: 2).

The Commission held many open meetings, covering much of the country, to receive the views of the public-and a few closed meetings (especially with senior officials of the government). It received 852 submissions altogether, including many presented to it at public meetings. It also received views of groups organised to participate in the process; they brought to the attention of the Commissioner views of overseas experts. The Commission considered that it obtained 'a picture of the hopes and concerns of the people of Fiji about their country's future' ${ }^{16}$ The media covered its meetings well. The Commission also sought information and ideas through papers from two sources: government departments and foreign experts, reflecting particularly on comparative research, and on issues it identified as critical to its recommendations. It supplemented this by visits to Malaysia, Mauritius and South Africa-all multiethnic states - to learn about their experiences, and meeting with a number of experts there, as well as in the US.

The Commission worked hard and in September 1996 produced a report, close to 800 pages long, providing the background to the review of the previous constitution and setting out the approach of the Commission, with clear explanatory notes-by far the most thorough and sophisticated analysis anywhere in the South Pacific of past practice, the rationale for change and the recommendations for a new constitution. What most

16 Reeves, Vakatora and Lal 1996: 59. Whenever possible, subsequent references to the 'Reeves Report', as it was called, will be presented in parenthesis within the body of my text, and referred to by paragraph, page or chapter number, as appropriate. 
surprised the people was unanimity of analysis and recommendations in a highly contentious area, thanks in part to the skills of Reeves who let the two local members resolve differences between them (and the communities they represented) as well as the close and amicable relationship that developed between Vakatora and Lal.

\section{Orientation of draft constitution (Reeves Commission)}

A major objective of the Reeves Commission was the promotion of racial harmony and national unity - by encouraging and facilitating the formation of multiethnic governments (para 2.69). The key to this was the electoral system, but it would involve removal or adjustment of the four principal problems that the commission had identified: communal representation, the ethnic base of political parties, majority government and the indigenous 'paramountcy' principle. It dealt with the principle of paramountcy by highlighting its role in the protection of the rights and interests of indigenous Fijians, rather than in the domination of other communities, though it did recommend special powers for indigenous institutions.

On power-sharing, the Commission rejected proposals either for a requirement that the prime minister should appoint a specified number of ministers from the different communities or that the constitution should entitle every political party that had secured at least 20 per cent of parliamentary seats to a proportionate share in the cabinet (p. 18), as they would not fundamentally alter the nature of politics. Instead, electoral and other incentives were needed for parties to cooperate, merge and broaden their appeal for support (paras 2.76, 9.96).

It believed that the overriding goals of multiethnic government, racial harmony and national unity could not be achieved until the electoral system moved away from communal seats to non-racial open seats. It reversed the proportion between the two types of seats in the 1970 constitution, proposing a 70-member House of Representatives with 45 completely open seats, and 12 seats for indigenous Fijians and Pacific Islanders, 10 for Indo-Fijians, one for Rotumans and two for General Voters (the current term for 'others').

For the Senate, each province would return two members, without any racial restriction of candidates or voters (plus some limited representation of small communities who might not otherwise make it to the House), 
thus building on the 'distinctive identity' of provinces (para 9.177). To facilitate racial integration, the Commission opted for the Alternative Vote (AV) system for both the House of Representatives and the Senate (Chapter 10), rejecting both first past the post (as undemocratic) and proportional systems (as encouraging voting by ethnicity).

The Commission made several other recommendations to ease ethnic tensions, provide a strong protection of human rights, ensure social justice (especially through affirmative action for the genuinely disadvantaged, and rules about national institutions like the civil service and judiciary reflecting the national make-up), and to reinforce what they hoped would be a less confrontational style in parliament by providing for a committee system to carry out much of the work of scrutiny of government.

It was the Commission's hope that all its proposals would be regarded as part of a coherent and interdependent scheme and a fair balancing of the interests of ethnic groups. But the Joint Parliamentary Select Committee divided chapters of the proposed constitution among its subgroups that looked at each chapter in isolation.

\section{Orientation of the 1997 constitution: Response to the Reeves Report}

The recommendations of the Commission met with great hostility among the indigenous Fijian and a section of the Indo-Fijian Muslim community. But the report was sent to the Joint Parliamentary Select Committee (JPSC) to discuss the proposals and to agree on amendments if necessary. ${ }^{17}$ Rabuka and the Indo-Fijian leader Jai Ram Reddy played a positive and constructive role. Many politicians were not happy at the emphasis on national identity at the expense of communal affiliations and institutions. A great number of them had become accustomed to and were comfortable with racially oriented electorates and politics. Others, who had not favoured the Commission's interest in comparative constitutions and experiences, emphasised the uniqueness of Fijis circumstances; and that, as the president cautioned, national harmony would only come from the recognition of different races, cultures and customs (Parliament of Fiji, Annex II (2)).

17 For a detailed account of the deliberations and decision of the JPSC and the Parliamentary debate, see Lal 1998: 86-102. 
Rabuka reminded the JPSC of the diversity of ethnic groups, cultures and faiths in Fiji, which give 'identity, solace and confidence to our citizens as individuals and distinct groups' (Parliament of Fiji, Annex IV(4)). In general, the JPSC accepted many of the values and principles of the Commission, but agreement on institutions was harder to negotiate, and in the end the provisions that would have given the two major communities equal rights in state institutions had to be watered down, maintaining the superiority of indigenous people. As with previous constitutions, Indo-Fijians had to yield to the indigenous-dominated military on political and constitutional matters.

The main amendments of the JPSC related to the system of government. It inverted the proportion between open and reserved seats. Out of a house of 71 members, only 25 seats would now be open; the balance would be divided among indigenous Fijians 23, Indo-Fijians 19, General Voters three and Rotumans one (representing slight over-representation of indigenous Fijians and the General Voters). This would reduce incentives to form multiethnic parties or mergers.

And the broadening of democracy was held back, by rejection of the proposal for an elected Senate. This eliminated further opportunities for electoral cooperation between parties of different ethnic communities. Its composition retained distinct ethnic elements: with 14 members nominated by the GCC, nine nominated by the prime minister, eight by the leader of the opposition and one by the Council of Rotuma. The requirement that at least nine of the 14 GCC-nominated members of the Senate approve certain legislation related to community rights especially on land, as well as the appointment of the president by the GCC rather than the more representative Parliament likewise retained the salience of the ethnic factor.

Perhaps realising that its decisions would reduce the prospect of power-sharing through the electoral process, The JPSC differed from the commission in opting for a mandatory coalitional government. ${ }^{18}$

18 One member of the JPSC, from the Fiji Labour Party, has explained why the Commission approach was rejected. His party, committed to non-racial distinctions, could not accept the notion of multiethnic government, but multiparty government, which the JPSC adopted, was more congenial (Krishna Datt, during a speech at the University of the South Pacific, 30 September 2003 (see Datt 2003)). The explanation is puzzling, since the vehicle for representation in the cabinet in the Commission proposal was parties, not ethnic groups as such. 
It decided that any party that obtained at least 10 per cent of the seats in the House of Representatives would be entitled to a proportionate number of ministries.

\section{After the 1997 constitution}

Preferential voting is an appealing idea. But it is not surprising that AV has been sceptically received by many in the Fiji Islands. The system, being strongly majoritarian, makes it very difficult for a new party—or a party trying to recover from a serious decline-to get into Parliament at all. The system also worked quite differently from what the Commission had expected; it did not encourage cooperation between ethnic groups, but led to shady deals across ethnic lines, geared mainly to weaken those parties within ethnic groups committed to racial integration.

The formula for a power-sharing executive was more likely to help smaller parties. But it did not work at all well because of the lack of commitment of the leading parties to sharing power. In 1999, when the FLP won and invited Rabuka's Soqosoqo ni Vakavulewa ni Taukei (SVT) to participate, the latter responded with a number of conditions, which Prime Minister Chaudhry interpreted (with almost indecent haste) as a rejection. In 2001, after a coup and return to civilian rule, the SDL leader invited that FLP to participate while suggesting that there was insufficient basis for a workable partnership', ${ }^{19}$ and went on to recommend a Cabinet with no FLP members.

Resolution of these disputes has involved repeated resort to the courts. In the first case, the Supreme Court held that Chaudhry was not bound to accept the conditions imposed by the SVT for joining government. ${ }^{20}$ In the second case, the Supreme Court held the prime minister in breach of the constitution. ${ }^{21}$ The matter went back to the court in 2004 over the precise interpretation of the constitution on allocation of seats. ${ }^{22}$

19 Qarase v. Chaudhry, [2003] F.J.S.C. 1, CBV0004.2002S (18 July 2003). The correspondence between the party leaders is appended to the decision.

20 President of Fiji Islands v. Kubuabola [1999] FJSC 8, Misc. Case No. 1 of 1999 (3 Sept. 1999).

21 Qarase v. Chaudhry [2003] FJSC 1 (the '2003 case').

22 In re the President's Reference, Qarase v. Chaudhry_Decision of the Court [2004] FJSC 1; MISC 001.2003 (9 July 2004). There was a dissenting judgment from Justice Gault on the issue of whether the prime minister could appoint senators or independent members of parliament as ministers without eating into his own quota in the Cabinet: In re the President's Reference, Qarase v ChaudhryDissenting Judgment [2004] FJSC 9; MISC 001.2003s. 
The rules for appointments to the Senate were also litigated: was the FLP to get all the Senate seats for the opposition if it was the only opposition party entitled to sit in the Cabinet? The Supreme Court said 'Yes', ${ }^{23}$ though one judge disagreed. ${ }^{24}$

These uncertainties in the constitution cannot be laid at the door of the Reeves Commission, but were consequences of the JPSC decisions. The Supreme Court emphasised:

Conventions cannot be the subject of judicial prescription. They are matters for the elected representatives of the people to develop in working out the future governance of their nation. That, it is hardly necessary to say, mandates a degree of give and take and good faith on all sides (Qarase v. Chaudhry [2003] FJSC 1, para. 107).

\section{One and a half more coups}

Although eventually a power-sharing Cabinet did come into being, before the 'conventions' that the Supreme Court had advised could develop, another coup befell the country a few months later, in 2006, this time led by the head of the military, Commodore Bainimarama. The 1997 constitution was put into cold storage, though the government declared its resolve to return to constitutional rule, albeit after some fundamental reforms, particularly towards a non-racial Fiji. In 2009, the Supreme Court, reversing lower courts, declared that the 2006 coup was unconstitutional, and that the 1997 constitution was still valid and ordered the restoration of lawful government. Bainimarama, then selfappointed prime minister and his attorney-general, Alyaz Sayed-Khaiyum, ignored the decision and dismissed the Supreme Court - perpetrating yet another coup. The purported revival of the 1997 constitution did have the effect of rallying around it several groups who were opposed to the coup, even though they had previously been lukewarm about it. This gave the constitition new legitimacy.

23 In re the Constitution, Reference by HE the President [2002] FJSC 1; MISC 001.2001S (15 March 2002). See also the Kubuabola 1999 case above.

24 In re the Constitution, Reference by HE the President (Dissenting Judgment) [2002] FJSC 3; MISC 001.2001S (Justice Amet). 
It must, however, be acknowledged that the first Bainimarama coup was popular with some sections of the people (mostly Indo-Fijian) and some civil society organisations. The 2007 project for a 'Peoples Charter for Change, Peace and Progress' 25 as a prelude to the making of the constitution, involving a significant number of organisations and well-respected individuals, was a sensible approach and produced some excellent proposals - though resisted by some, because of its connections with Bainimarama and his coup. But it lost its legitimacy, and many supporters, as the regime moved to the suppression of basic human rights and increasingly vindictive administration. Bainimarama and SayedKhaiyum seemed to change their mind about a return to democracy and continued their rule, backed by the armed forces, until September $2014 .^{26}$ Fiji was ruled primarily through a series of decrees, passed at the will of the prime minister (and legally unchallengeable), several of them quite draconian, targeting sources of independent thought such as the media and legal profession-and destroying the rule of law. The great harm that coups and the military rule do to democracy and the rule of law is seldom factored into discussions of the renewal of democracy. However democratic the new constitution, the system of government and the people's fear of the administration do not recover easily from the scars of the military regime.

Under some pressure from the international community, in early 2012, the government promised, yet again, to initiate a process for the writing of a new constitution, followed by elections. At this stage, I was approached by Sayed-Khaiyum to head the commission responsible for preparing the constitution, within broad guidelines. ${ }^{27}$

25 National Council for Building a Better Fiji, 2008. The Charter process had task forces on Good Governance (Legal, Political, Institutional and Constitutional Reforms); the Economy; and Social Cultural Identity and Nation Building.

26 I believe that Bainimarama and Sayed-Khaiyum (or at least the latter) did genuinely intend to move quickly to a new constitution. Sayed-Khaiyum asked me soon after the coup to go to Fiji to help write the constitution. I was unable to accept as I had just taken a senior UN post in Nepal to help in that country's constitution. In December 2008, I was asked by the Secretary-General of the UN to go to Fiji to explore the possibility of reconciliation between different political factions, leading eventually to a new constitution (Bainimarama had asked the Secretary-General for UN mediation). Based on our report, the Secretary-General agreed. I was to return to negotiate the terms and procedure for UN involvement, but the plan collapsed after it became clear that Bainimarama was not serious - perhaps just buying time?

27 The other members of the Commission were Taufa Vakatale, Penny Moore, Satendra Nandan and the South African Christina Murray. 


\section{Return to constitutional democracy?}

\section{The Ghai Commission}

I agreed with most objectives the government had set out as the basis of the constitution except for immunity provisions. I was also impressed with the government's emphasis on a participatory process—and above all with its agreement to the independence of the commission and the making of the final decisions on the constitution by a representative constituent assembly. ${ }^{28} \mathrm{I}$ insisted, with success, on lifting of the restrictions on the right of assembly and public access to the Commission.

In order to ensure the government commitment to these assurances, I drafted a decree setting out the principles and objectives of the constitution, and the procedure (including the lifting of bans on meetings and security against victimisation in respect of submissions made to the Commission-and no immunities). The government, soon realising it had made a mistake with the process, divided the draft decree into one on the Commission and the other on the constituent assembly-and inserted in both the requirement that the new constitution must provide wide-ranging immunity for the military and other groups and individuals involved in the various past coups.

The new constitution was to result from full, inclusive and fair participation of Fijians. The Commission was to study the circumstances and needs of Fiji, and its constitutional history 'to avoid the mistakes of the past', carry out and commission research, use experts, keep the people informed, visit 'as many parts of the country as possible' (Fiji Constitutional Process (Constitution Commission) Decree 2012 (Decree No. 57 of 2012) s. 7(1) (b)), hold public meetings to receive oral and written submissions, which they were to analyse 'scientifically' and summarise in a report, prepare a draft constitution and any changes to existing laws that the constitution would require, and present it to the people along with an 'explanatory

28 When so invited by the Fiji government, I was confronted with the dilemma that I had faced a few years previously in my own country, Kenya, when the unpopular and dictatorial president Moi asked me to chair the Constitutional Review Commission. I consulted widely with civil society organisations, religious groups and friends on whether I should accept the offer. I did accept but on conditions that the president was not happy with but conceded-and the Commission did produce a good draft that was largely enacted into law. I made similar consultations in Fiji. 
report'. It was then to seek and collect the views of the people on the draft, and submit the draft with those reactions for consideration by a constituent assembly. All in six months.

The draft constitution was to meet the needs of Fiji and the aspirations of its people, unite those people, be 'appropriately designed' to achieve 'true democracy, and respect for, and protection and promotion of human rights' (s. 3(d)). Another provision listed certain 'non-negotiable principles and values': (i) a common and equal citizenry; (ii) a secular state; (iii) the removal of systemic corruption; (iv) an independent judiciary; (v) elimination of discrimination; (vi) good and transparent governance; (vii) social justice; (viii) one person, one vote, one value; (ix) the elimination of ethnic voting; (x) proportional representation; and (xi) voting age of 18 years (s. 3(e)).

The commission prepared a small book to explain to the people both the objectives and process of the review, and held a number of meetings, on our own and through civil society groups to promote awareness of issues and options (Constitution Commission 2012). After that the process of consultation was very intense, with the Commission aiming to visit all areas of the country and holding hearings in 110 venues. We estimate that we heard from a very wide range of people and organisations - and at a late stage, the military. We also received many submissions by post and emails (locally as well as from the diaspora).

A remarkable consensus within the Commission enabled us to meet our deadline of the end of December 2012. By this time, we had lost the confidence of the prime minister and the attorney-general, who curtailed our activities (the former threatened to deport me if I did not stop meeting with trade unions, civil society, and political parties-I did not and he did not). Copies of our draft constitution were confiscated from the printers, and a small number was burnt. However, in accordance with the Decree we were able to present the draft constitution to the president, who, having praised our report at a farewell reception by the Commission, was subsequently compelled by the prime minister to strongly criticise it. We were stopped by the government from the next and final task-that of engaging the public on our recommendations and preparing a dossier of their reactions for the constituent assembly. In fact, the government ensured that there would be no constituent assembly, and took over the task of writing and promulgating the constitution-taking considerably longer than it promised, concentrating on developing an electoral system that would ensure it victory. 


\section{Orientation of the 2012 draft}

I do not intend to examine the provisions of the Commission's draft constitution in detail-partly because it never became a constitution! My focus is on our analysis of the problems facing the country, and how these could be resolved, and how to give effect to the fundamental principles that the constitution must incorporate. The Ghai Commission agreed with many of the objectives of the Reeves Commission, and indeed the fundamental principles as set out by the government. As far the Reeves Commission was concerned, there were differences of approach, it being more cautious and conservative than us. As far as the government was concerned, despite promises to make submissions to us, neither the prime minister nor the attorney-general made submissions, though we were given to understand that the government position was no different from that of the military.

\section{The issues}

\section{Ethnicity}

There is wide acceptance among scholars and the public that the most fundamental causes of Fiji's contemporary problems lie in history and in its various constitutions shaped by that history. At the root is the organisation of politics, state and economy on the basis of ethnic communalismthe colonial legacy. This much is evident from the narratives of Fiji's two major communities: both victims of forces beyond them, deprived of free choice and will and victims of the colonial system. Instead of dealing with the forces that subordinated and in many respects exploited them, they regarded the other community as the obstacle to the advancement of its members - and made little effort to understand the suffering of the other.

\section{Culture}

We also noticed a crisis of culture. Fiji is caught up in a culture that is based on the organisation of an outdated economy. The demands of people embedded in this culture (for free and better education, health, housing and transport) cannot be met without a radical change in that culture and the values and institutions that sustain it. 'Culture' as applied to indigenous Fijians has become very encompassing, and deeply attached to religion, politics and economy, which cause particular problems in 
organising the state and planning the economy. Privileging one culture or religion above others in a multiracial society is no recipe for peace, unity or development. This problem is compounded by generational change, which makes culture a source of conflict not as between different cultural traditions but also within each culture.

\section{Lack of trust in public institutions}

People have little trust in political leadership and public institutions, a result of ethnic conflict and increasing levels of corruption compounding the sense of crisis that is widespread. The rule of law (for long a positive and important feature of state and society in Fiji) has been undermined. The frequency of coups has produced a feeling of hopelessness all too evident to the Commission in public hearings.

\section{Democratic deficit and weakness}

Fiji's democracy is without deep roots, without a real understanding of its importance or procedures. Racial politics have dominated at the expense of the values of democracy; operating within previous frameworks well past their usefulness. The succession of coups and military or militaryinfluenced governments have also undermined democratic values and prevented the accumulation of democratic experience.

\section{Approach of the Commission}

The Commission developed an approach to the issues founded in the belief that the fundamental need was to shift the identity, politics and institutions of the people of Fiji from their bases in community to those based on equal citizenship. It suggested that the challenge was to create out of its diverse communities an identity as a nation founded on common values and aspirations, without dispensing with its rich cultural diversity. Once the foundations of that national identity have been agreed upon ('nation-building'), the values, institutions and procedures of the state must be reformed to reflect the Fiji nation and its aspirations ('state-building' or 'restructuring').

The Commission looked for approaches and solutions through which every community would be better off than otherwise. It proposed greater separation between state and society. The shift to non-racial state values and structures would be easier if the values, culture and practices of ethnic communities became their own responsibility. In this way, institutions 
like chieftaincy or religious practices would not be threatened or undermined but become matters for the community. The separation of state and society would actually protect culture and make it possible for members of ethnic communities to cooperate and work constructively in the public sphere, in the affairs of the state as well as the economy. For these reasons, the Commission recommended that the GCC (which the government had abolished) should be separated from the state, becoming purely a voluntary institution for communal affairs of Fijians.

The Commission had become conscious of how relatively unorganised the people were, except for the guidance and structure provided by faith organisations or through traditions and culture (especially for indigenous Fijians), and thus of their lack of knowledge of the purpose and nature of the state, or their own rights as individuals and organisations. It decided that civil society, even with its weaknesses, must be encouraged, including because, as the Reeves Report put it, civil society has a vital role to play in providing opportunities for members of different communities to come together (para 3.52).

\section{Land}

The Commission was aware that the customary land system had protected the indigenous communities, and it received advice that the system, with administrative reforms, could form a good basis for the developmental use of land. So it proposed a mechanism for a national dialogue on land involving state bodies, land owners (most of these Fijians) and tenants (mostly Indo-Fijians). The draft proposed some underlying principles to guide negotiations including security of land rights, better administration of land, responsible use of land, and participation and consultation. However, to increase the sense of security, all existing rights in land were recognised, as was the prohibition on permanent alienation of customary land except to the state, as well as freehold land and rights to it recognised in existing law.

Under the 1997 constitution, 'social justice' meant affirmative action, especially_as applied_for Fijians. Yet people from both main communities were poor and victims of discrimination. So the Commission relied upon the broad permission for affirmative action in the human rights chapter, and the recognition of economic social and cultural rights, such as education, health, food and water as enforceable, drawing on constitutions such as those of South Africa and Kenya. An addition was 
a right of access to markets-reflecting submissions the Commission received about the difficulties of access in the light of inadequate roads and boat services.

\section{Conclusion}

\section{Process}

Fiji has had, in 45 years, four constitutions, five coups and a period of eight years without a constitution. The fact that the last military regime felt it necessary to establish a constitution and then hold elections under it may suggest the importance, or even the necessity, of a constitution. A country with Fiji's fragmented communities, deep social divisions, diverse languages, religions and cultures, and lack of nationalism needs some sort of consensus on key institutions and procedures to run the country prescribed in a constitution. Fiji's history shows that broad consent is necessary to maintain the semblance of a state, a functioning economy, and a measure of law and order-and the evasion of sanctions from abroad. Constitutions and the making of them have therefore been a central aspect of Fiji's history.

The alternative is military rule, of which Fiji has ample experience (but surprisingly missing otherwise in the South Pacific). These days a constitution serves another purpose: warding off the disapproval of, even sanctions by, other states or interstate organisations (an important factor for Fiji's military that flourishes on its peacekeeping role-in other countries). Fiji's retreats from military regimes were perhaps dictated more by this consideration than legitimacy at home-for legitimacy at home was often secured by the military regimes through substantial support from important sections of indigenous, European and South Pacific communities.

The processes of law-making were marked by the circumstances surrounding its period. The 1970 constitution was to grant independence and establish the system of government. Like most decolonising constitutions the process was negotiated, not open and participatory, with Britain playing a major role. ${ }^{29}$ The constitution itself was designed

29 Some other Pacific constitutional processes were far more open, especially Papua New Guinea and Vanuatu. For a comparative study of constitution making in the South Pacific, see Ghai 1988a. 
to protect indigenous Fijian interests, which it did at great cost to ethnic trust. The process was highly secretive, on the initiative of local negotiating parties, not Britain. Certainly compared to constitution-making in other parts of the South Pacific, Fiji was the least democratic.

The 1990 process was more open and participatory. But it was still heavily influenced by political parties, and the military. As an exercise in genuine participation, or consensus-building, the process was a failure. The Manueli Committee was seeking comments on a draft prepared by Rabuka and his advisers. The military kept a firm control over the process, so that the resulting constitution was not negotiated, but imposed.

In substantive terms, the constitution represented an intensification of the racial factor and removed the few features not based on race as such. But it contained the seeds of its own destruction by being so blatantly racist, and undermining Fijian unity, that it was hard for the international community to do other than oppose it.

The 1995-97 process was excellent in many ways, but had two weaknesses. The Commission spent a fair bit of time educating itself, but did little to educate the people on the issues, which probably affected the quality of public participation (dominated as it was by political parties). One result of this might have been that though a large number of individuals and organisations made their submissions to the Commission, they were mostly cast in the old moulds of racial politics (delivered duly by the followers of old, established parties, on party instructions). Second, and perhaps more seriously, the report and recommendations of the Commission were presented to parliamentarians, rather than to the people, thus giving politicians the ultimate decisions, with the intrusion of racial politics as well as the convenience of politicians, with the focus shifting away from the national (as recommended by the commission) to the racial.

The process under the 2012 Commission was different from any previous process, to some extent building on the Reeves model. The process was highly participatory (despite many restrictions by, and fear of, the military). It would have been the most participatory in the South Pacific if the military had not truncated it, cutting out public debates on the Commission's draft, and then the convening of the constituent assembly, which would have made the final decisions on the constitution. It would have made a difference also if public debate on anything to do with the constitution had not been curtailed by the government 
until nearly the start of the process, making civil education almost impossible. This degree of democracy was too much even for the regime that claimed to have its basis in public support. Political parties had little impact on the process, and, in the early stages, were not keen on participation (but did warmly endorse the draft in a joint statement of all parties - a rare occurrence in Fiji). The government and the military (insofar as it is possible to separate the two) had slightly more impact, but did not really like the process as it was eventually inscribed in the decrees. And if the recommendations of the Reeves Commission were mutilated by politicians, the recommendations of the 2012 Commission were far more extensively affected by the military-based government. While the 2013 constitution has some echoes of the $2012 \mathrm{draft}$, the government introduced the provisions it had wanted all along, without fulfilling its commitment to a constituent assembly.

\section{Orientation}

Each of the constitutions had a clear orientation. The independence constitution was built on the colonial model (of divide and rule); in this respect Fiji was unusual, for in most former colonies, the independence constitutions represented a major departure from the colonial mode of representation and governance. The 1970 constitution seemed a curious mixture of consociation and integration, but really it was designed for the dominance of indigenous Fijians. In the background was the military, which would be run by the indigenous aristocracy, which transcended civilian and military rulers. Then again, Indo-Fijians regarded the constitution as transitional, leading to a fully non-racial and democratic dispensation (and insisted, successfully, on the review of the electoral system to promote integration, before the following election; Mara resisted it but a commission was set up. Its recommendations for proportional voting were disregarded).

All subsequent constitutions had the stamp of the military. Whether Ratu Mara used him or not, Rabuka demonstrated the teeth of the army as well as the collaboration between the army and aristocracy. The 1990 constitution demonstrated the superiority of the army (over the aristocracy) and its conception of 'indigenous' rule, founded on the clear dominance of the indigenous communities, of the eastern origin. It vested indigenous leaders and institutions with impunities, and dealt a severe blow to the principle of the separation of powers, which had until then 
commanded considerable respect. But by the very virtue of undisputed indigenous rule, Rabuka created major divisions within the indigenous community — of which he became a victim as the outlines of the 1997 constitution unfolded.

The 1997 constitution was not the Reeves constitution. The Reeves Commission had the vision of racial harmony and national unity, moving away from ethnic political parties and the racially based electoral system. It emphasised human rights and the equality of all the people of Fiji, without encroaching on the traditional rights of indigenous communities to their land as well as culture, manifested in the Great Council of Chiefs. Its caution in that respect may be seen as a kind of a transitional constitution, whose full realisation would have been the 2012 constitution by the Ghai Commission. The 1997 constitution was really the constitution of politicians brought up in the traditions of the 1990 constitution, but with greater attempts at a multiracial governance system. Their error was to disregard the expert advice of the Reeves Commission-a not unusual vice of politicians everywhere.

In one sense the 2012 Commission aimed at the full realisation of the objectives of the Reeves agenda, but with a fundamental restructuring of institutions. In many ways, it was faithful to the professed objectives of the Bainimarama and Sayed-Khaiyum regime, perhaps too faithful, so that it had to be destroyed-burnt. Together Bainimarama and SayedKhaiyum devalued the notion of a constitution driven by the people, or indeed of a constitution. The decree, a magical trick by which they had ruled Fiji for nearly seven years, continues to reign-in spirit. Fijians all (iTaukei (indigenous Fijians), Indo-Fijians, Euro-Fijians, Sino-Fijians and the South Pacific Islanders) will have to wait for a people-driven constitution, which is the foundation of their polity and which respects their identity as Fijians above all.

\section{References}

Abrahamson, Allen. 2009. 'The lie of the land: Suturing the jural and the ritual in Fiji, Western Pacific.' In Law and Anthropology: Current Legal Issues Volume 12, edited by Michael Freeman and David Napier, pp. 269-91. Oxford: Oxford University Press. DOI: dx.doi.org/10.1093/ acprof:oso/9780199580910.003.0011. 
Arjomand, Saïd Amir (ed.). 2007. Constitutionalism and Political Reconstruction. Leiden and Boston: Brill.

Choudhry, Sujit (ed.). 2008. Constitutional Design in Divided Societies: Integration or Accommodation? Oxford: Oxford University Press.

Conference on Democratic Transition and Constitution. 2001. FRIDE/ Gorbachev Foundation of North America, Madrid, 19-27 October.

Constitution Commission. 2012. Building the People's Constitution: Your Responsibility A Guide to Constitution Making for the People of Fiji. Suva: The Constitution Commission.

Cottrell, Jill and Yash Ghai, 2010. 'Between coups: Constitution making in Fiji.' In Framing the State in Times of Transition: Case Studies in Constitution Making, edited by Laurel E. Miller with Louis Aucoin, pp. 275-308. Washington, DC: United States Institute of Peace.

Datt, Krishna. 2003. Speech at the University of the South Pacific Conference on Democracy and Good Governance, 30 September (on file with author).

Elster, Jon. 2001. 'Ideal and reality in constitution-making'. Paper prepared for Conference on Democratic Transition and Consolidation organised by the Fundación para las Relaciones Internacionales y el Dialogo Exterior and the Gorbachev Foundation of North America, Madrid, October 2001. Online: www.constitutionnet.org/files/ Elster\%20Fride.doc (accessed 25 January 2017).

France, Peter. 1969. The Charter of the Land: Custom and Colonisation in Fiji. Melbourne: Oxford University. Press.

Freeman, Michael and David Napier (ed.). 2009. Law and Anthropology: Current Legal Issues Volume 12. Oxford: Oxford University Press.

Ghai, Yash. 1988a. 'Constitution making and decolonisation'. In Law, Politics and Government in the Pacific Island States, edited by Yash Ghai, pp. 1-53. Suva: Institute of Pacific Studies of the University of the South Pacific.

- 1988b. 'Systems of government I'. In Law, Politics and Government in the Pacific Island States, edited by Yash Ghai, pp. 54-75. Suva: Institute of Pacific Studies of the University of the South Pacific. 
1988c. 'Systems of government II'. IN Law, Politics and Government in the Pacific Island States, edited by Yash Ghai, pp. 76-105. Suva: Institute of Pacific Studies of the University of the South Pacific.

_- 1988d. 'Political consequences of constitutions'. In Law, Politics and Government in the Pacific Island States, edited by Yash Ghai, pp. 350-73. Suva: Institute of Pacific Studies of the University of the South Pacific.

—_ 1990. 'A coup by another name? The politics of legality.' Contemporary Pacific, 2(1): 11-35.

Ghai, Yash (ed.). 1988. Law, Politics and Government in the Pacific Island States. Suva: Institute of Pacific Studies of the University of the South Pacific.

[Ghai, Yash]. 1991. The Fiji Constitution of 1990: A Fraud on the Nation (A Report by the Fiji Labour Party and the National Federation Party). Nadi: Sunrise Press. (I wrote this report. My name does not appear on the title page, but see the preface).

Ghai, Yash and Jill Cottrell. 2007. 'Constitutional engineering and impact: The case of Fiji.' In Constitutionalism and Political Reconstruction, edited by Saïd Amir Arjomand, pp. 159-91. Leiden and Boston: Brill.

- _ 2008. 'A tale of three constitutions: Ethnicity and politics in Fiji.' In Constitutional Design for Divided Societies: Integration or Accommodation?, edited by Sujit Choudhury, pp. 287-315. Oxford: Oxford University Press.

Halapua, Winston. 2003. Tradition, Lotu and Militarism in Fiji. Lautoka: Fiji Institute of Applied Studies.

Lal, Brij V. 1992. Broken Waves: A History of the Fiji Islands in the Twentieth Century. Honolulu: University of Hawai'i Press.

—_. 1998. Another Way: The Politics of Constitutional Reform in PostCoup Fiji. Canberra: Asia Pacific Press.

Manueli, Paul. 1989. Report of the Fiji Constitution Inquiry and Advisory Committee, Suva: Fiji Constitution Inquiry and Advisory Committee, August. 
Mara, Kamisese. 1997. The Pacific Way: A Memoir. Honolulu: University of Hawai'i Press.

Miller, Laurel E. with Louis Aucoin (eds). 2010. Framing the State in Times of Transition: Case Studies in Constitution Making. Washington, DC: United States Institute of Peace.

National Council for Building a Better Fiji (NCBBF). 2008. Online: www.pidp.org/pireport/special/draftcharter.pdf (accessed 24 January 2017).

Pacific Islands Development Program website. Online: www.pidp.org/ pireport/special/draftcharter.pdf (accessed 24 January 2017).

Parliament of Fiji. 1997. Report of the Joint Parliamentary Select Committee on the Report of the Fiji Constitution Review Commission. Parl. Paper No. 17.

Reeves, Paul, Tomasi Vakatora and Brij V. Lal. 1996. Towards A United Future: Report of the Fiji Constitution Review Commission. Suva: Government Printer (Parliamentary Paper No. 34 of 1996, Parliament of Fiji).

\section{Cases}

In re the Constitution, Reference by HE the President (Dissenting Judgment) [2002] FJSC 3; MISC 001.2001S (Justice Amet).

In re the Constitution, Reference by HE the President [2002] FJSC 1; MISC 001.2001S (15 March 2002).

In re the President's Reference, Qarase v. Chaudhry-Decision of the Court [2004] FJSC 1; MISC 001.2003 (9 July 2004).

In re the President's Reference, Qarase v. Chaudhry-Dissenting Judgment [2004] FJSC 9; MISC 001.2003s.

President of Fiji Islands v. Kubuabola [1999] FJSC 8, Misc. Case No. 1 of 1999 (3 Sept. 1999).

Qarase v. Chaudhry [2003] FJSC 1. 
This text is taken from Bearing Witness: Essays in honour of Brij V. Lal, edited by Doug Munro and Jack Corbett, published 2017 by ANU Press, The Australian National University, Canberra, Australia. 